\title{
Determinants of Bank Profitability in Transition Countries: What Matters Most?
}

Dr Khurshid Djalilov and Professor Jenifer Piesse

\begin{abstract}
The aim of this paper is to investigate the determinants of bank profitability in the early transition countries of Central and Eastern Europe (CEE), and in the late transition countries of the former USSR. We apply a GMM technique for the period covering 2000-2013. The results show that profitability persists and the determinants of bank profitability vary across transition countries. Particularly, the banking sector of early transition countries is more competitive. However, the impact of credit risk on bank profitability is positive in early transition countries, but negative in late transition countries. Government spending and monetary freedom negatively influence bank profitability only in late transition countries. Moreover, better capitalised banks are more profitable in early transition countries implying that these banking sectors are more robust. A range of possible approaches that governments can take to further develop banking sectors are discussed.
\end{abstract}

JEL classification: C23, G21, L2, P27

Keywords: Transition countries, bank profitability, government spending, monetary freedom 


\section{Introduction}

It has now been almost three decades since the collapse of the socialist system, and many previously centrally planned economies have established market-based economies. Most countries have followed a similar approach to overcoming the legacy of the Soviet system. Although the speed and sequence of reform varied across countries, all were influenced by the World Bank and International Monetary Fund, the so called Washington consensus, which focused on liberalisation, stabilisation and privatisation. The soviet-style mono-banks were abolished and restrictions on the internal convertibility of money removed, state control of interest rates was suspended, and the privatisation of state-owned banks took place very early although with varying degrees of success (Fries et al., 2002). In addition, transition countries completed two major reforms. The first was the introduction of a two-tier banking system to separate the central bank from the commercial banking sector. This also included the division of large industrial banks into smaller organisations to create competition in the sector. This resulted in a move away from a system where the primary goal of the banks was to transfer state funds to state-owned enterprises for investment projects approved by central planning to a system appropriate to a market economy. The incumbent systems were inefficient in terms of resource allocation and the quality of banking supervision, and risk assessment was poor. The second was the establishment of a system of financial intermediation to increase saving and investment. The importance of these reforms was recognised by the governments of all the transition economies. However, while the countries of Central and Eastern Europe (CEE) and the Baltic States (the early transition group) began structural reforms in the 1990's, and have to a large extent created efficient banking sectors, in the former Soviet Union states (the late transition group) this process is still not complete.

Although the share of bank domestic credit over GDP is relatively higher in the early transition countries, it can be shown that the banks are universally the most important 
component of the financial sector (Table 1). Considering the vital role of banking in developing and transition countries, improvement in profitability can have a significant impact on the allocation of financial resources (Sufian and Habibullah, 2010). Moreover, recent studies show that a profitable banking sector better withstands negative shocks and thus contributes to the stability of the financial system (Athanasoglou et al., 2008). Therefore, research that investigates the factors driving bank performance and profitability is important in order to inform strategies for future financial and economic development.

Table 1. Domestic credit provided by banks (\% of GDP)

\begin{tabular}{|c|c|c|c|c|c|c|c|c|}
\hline Year & \multicolumn{4}{|c|}{ Late Transition countries } & \multicolumn{4}{|c|}{ Early Transition countries } \\
\hline & Armenia & Azerbaijan & Georgia & Kazakhstan & $\begin{array}{l}\text { Czech } \\
\text { Republic }\end{array}$ & Estonia & Hungary & Lithuania \\
\hline 2013 & $\begin{array}{l}43.80 \\
(46.00)\end{array}$ & $\begin{array}{l}25.36 \\
(25.49)\end{array}$ & $\begin{array}{l}39.83 \\
(42.91)\end{array}$ & $\begin{array}{l}35.58 \\
(39.08)\end{array}$ & $\begin{array}{l}55.28 \\
(66.97)\end{array}$ & $\begin{array}{l}73.67 \\
(71.60)\end{array}$ & $\begin{array}{l}50.72 \\
(64.69)\end{array}$ & $\begin{array}{l}46.21 \\
(51.05)\end{array}$ \\
\hline
\end{tabular}

Source: World Bank World Development Indicators 2014. The numbers in brackets show the domestic credit provided by the financial sectors (\% of GDP)

Recent studies largely focus on the determinants of bank profitability in developed and developing countries (Athanasoglou et al., 2008; Dietrich and Wanzenried, 2011; GarcíaHerrero et al., 2009; Trujillo-Ponce, 2013). However, research directed to transition countries, and particularly the countries of the former USSR, is limited. Moreover, banks behave differently under different institutional settings, which implies that the results obtained for developed and developing countries may not apply to those in transition to a market economy (Berger et al., 2001; Berger and Udell, 2002; Haselmann and Wachtel, 2007). In addition, transition countries have a number of unique characteristics, and government policies and regulations can differ from those in developed and developing countries. The relevant studies mostly consider bank-specific, industry-specific and macroeconomic variables as determinants in an investigation of bank profitability. However, these do not take account of environmental conditions, government policy and regulation, and thus it is premature to apply the results to transition country banking sectors. Therefore, this 
paper also includes national environmental factors such as government spending and fiscal and monetary freedom as they may be important in explaining bank profitability.

The aim of this paper is to investigate the determinants of bank profitability for early (CEE and the Baltic States) and late (former USSR) transition countries for the period 20002013. This study is important as it contributes to the existing literature in several aspects. Firstly, it uses a richer dataset that covers the period before, during and after the recent global crisis period (2000-2013) for these countries. Second, it includes the special conditions of early and late transition countries, and allows an examination of environmental factors and their impact on bank profitability. Third, existing studies on bank profitability use either static (Pasiouras and Kosmidou, 2007; Staikouras and Wood, 2004; Sufian and Habibullah, 2010) or dynamic approaches (Athanasoglou et al., 2008; Dietrich and Wanzenried, 2011). However, in this paper robust conclusions can be drawn using both approaches.

This paper builds on research by Athanasoglou et al. (2008), Dietrich and Wanzenried (2011) and Sufian and Habibullah (2010). The results are interesting not only for academics and bank officials, but also for other stakeholders such as policy-makers, central bankers and other financial authorities. The results show that the quality of asset allocation needs further improvement in late transition countries. In addition, better capitalised banks are found to be more profitable in early transition countries. Moreover, indicators of economic freedom, such as government spending and flexible monetary policy, still have a negative impact on bank profitability in late transition countries. This suggests that policy-makers need to consider further reform in these areas.

The paper is structured as follows. Section 2 highlights the difference between early and late transition countries and discusses the relevant empirical literature. Section 3 
describes the data and methods used. Section 4 presents the findings from the empirical analysis, and Section 5 concludes and suggests some policy recommendations.

\section{Theoretical background}

\subsection{Economic transition in the countries of the former USSR}

Over the last three decades, a plethora of studies have focused on the transition of countries of CEE from a system of central planning to a market economy (Fries et al., 2002; Fries and Taci, 2005; Kenjegalieva and Simper, 2011). However, the majority of the former Soviet countries have been largely ignored due to the paucity of reliable information (Djalilov and Piesse, 2011; Schobert, 2006). This is a serious omission as these countries are substantially different from the early transition countries in CEE in a number of important respects. Firstly, the former Soviet countries were controlled by the communist regime for more than seventy years. This resulted in a lack of a national collective memory of any other form of economic organisation, and the institutions in these countries were largely impenetrable. Furthermore, the leadership had no experience of managing a domestic market economy prior to the collapse of the Soviet Union in 1991 as decisions were made centrally. When reforms to establish a market economy in the Baltic States and in several countries in CEE began during the Gorbachev era of the late 1980s, other countries of the former USSR did not follow suit. Thus, there existed a sharp contrast between countries such as Hungary, Poland and the former Czechoslovakia, and the Baltic States, which only had a system of central planning for the period following the Second World War until the 1990s, and those in Central Asia. This historical legacy has had a significant impact on how quickly a market economy can be established, and emphasises the importance of the initial conditions at the start of the transition on the direction and speed of financial sector development and its impact on financial development and economic growth. 
Secondly, many former Soviet countries are rich in mineral and energy resources. This has implications for their economic growth, but also provides a source of potential internal conflict that is associated with the problem of resource allocation. Thirdly, some former USSR countries, especially those located in Central Asia, are geographically extensive, and the political instability in neighbouring countries, such as Afghanistan, can be contagious. For these countries, maintaining economic growth and ensuring financial stability are vital to retaining social cohesion and sustained development. Fourthly, early (CEE and the Baltic States) and late (former USSR) transition countries have taken significantly different approaches to the transition from a planned to a market economy. The first group pursued a revolutionary approach and most of them became EU members in 2004, while late transition countries took an evolutionary (step by step) approach, which has lasted for more than two decades. Therefore, research distinguishing these two groups of transition countries provides new empirical findings.

\subsection{The Literature on the determinants of bank profitability}

The existing literature uses several variables, both internal and external to the organisation, to explain bank profitability, depending on the focus of the research. The microeconomic determinants of profitability are those linked to management, strategy and performance, whilst the macroeconomic determinants relate to the nature of the national institutions and economic environment within which the banks operate.

Following earlier studies (Bourke, 1989; Short, 1979) recent research has examined bank profitability at the country level (Ben Naceur and Goaied, 2008; Berger, 1995a; Daly and Zhang, 2014; Guru et al., 2002; Mamatzakis and Remoundos, 2003; Pasiouras and Kosmidou, 2007; Sufian and Habibullah, 2012, 2010) or cross-country analyses (Albertazzi 
and Gambacorta, 2009; Goddard et al., 2004a; Hsieh and Lee, 2010; Molyneux and Thornton, 1992; Naceur and Omran, 2011). Although the results vary considerably as data availability is not consistent across countries there are some common elements, particularly in the choice of elements internal to the firm, such as size and capital and risk management, that impact bank profitability.

Size is an important determinant of performance if there are economies or diseconomies of scale. Additionally, some studies claim that the effect of external variables on profitability is closely linked to bank size (Demirgüç-Kunt and Huizinga, 2000). Based on these results the studies can be divided into two groups: those that find a positive link between size and profitability (Flamini et al., 2009; Smirlock, 1985) and those that find this to be negative (Pasiouras and Kosmidou, 2007; Stiroh and Rumble, 2006). The positive effect is driven by the finding that larger banks have more diversification in their products and services, and this reduces the level of risk and thus results in higher operational efficiency and profitability. In addition, larger banks can raise relatively cheap capital and thus appear to be more profitable (Short, 1979). Furthermore, some studies find that in a non-competitive environment larger banks with a significant market share enjoy higher profits by offering lower deposit rates, which are considered less risky, and by maintaining high lending rates (Flamini et al., 2009). In contrast, the opposing view is that an increase in bank size leads to higher levels of marketing and operational and bureaucratic costs, and results in a negative link between profitability and size. Thus, the scale effect on profitability remains ambiguous.

Risk management is also included in most studies and poor asset quality and low levels of liquidity are two major factors influencing bank failure in the sector. Two types of risk, credit and liquidity risk, are most commonly addressed in these studies. Particularly during periods of increased uncertainty, banks tend to diversify their portfolios and raise their liquid holdings to reduce their risk. The ratio of loan loss provisions to loans is often used as 
a proxy for credit risk (Athanasoglou et al., 2008; Trujillo-Ponce, 2013) with a higher ratio indicating lower credit quality, which ultimately leads to a lower profitability. However, as liquidity management, asset management and the level of cash flow to maintain the ability of the bank to meet current liabilities when they come due, custom and practice suggests that the ratio of loans to total assets is the preferred metric (Sufian and Habibullah, 2010). Again, results vary on the sign of this variable when determining the link between liquidity and profitability from positive (Bourke, 1989) to negative (Molyneux and Thornton, 1992). However, existing studies find a negative link between credit risk and profitability (Miller and Noulas, 1997).

Capital is the third common variable that is internal to the bank, and this plays an important role in the determination of bank profitability in many studies. This may proxy risk and regulatory costs in the presence of capital requirements (Flamini et al., 2009). However, the link between capital and profitability is again controversial in the literature. The traditional view suggests that a higher capital asset ratio increases funding costs and thus lowers profitability, as many papers consider the cost of capital, particularly, the cost of equity to be the most expensive bank liability in terms of expected return (García-Herrero et al., 2009; Trujillo-Ponce, 2013). Some studies suggest that an unexpected increase in capital raises profitability linking this into two hypotheses. The first supports the view that increasing capital lowers payments on unsecured debt, while the second states that banks provide signals of better future prospects by increasing their capital (Berger, 1995b). Some studies find a positive relationship between capitalisation and bank profitability (Angbazo, 1997; Demirgüç-Kunt and Huizinga, 1999; Drakos, 2003; Maudos and De Guevara, 2004; Saunders and Schumacher, 2000), while others suggest the link to be absent (before the global crisis 2007-2009) and negative during the crisis (Dietrich and Wanzenried, 2011). 
With respect to the macroeconomic and institutional variables, GDP growth, inflation and sector concentration are common in the literature as determinants of bank profitability. Profitability is found to be sensitive to GDP growth, suggesting that demand for loans increases during cyclical upswings, and that existing studies find the link between GDP growth and profitability to be positive (Dietrich and Wanzenried, 2011; Flamini et al., 2009; Goddard et al., 2004a; Trujillo-Ponce, 2013). Alternatively, when GDP growth slows, particularly during crises and recessions, the credit quality of banks worsens thus reducing profitability. However, the impact of inflation on profitability is ambiguous depending on whether inflation is anticipated or not (Perry, 1992). If inflation is anticipated banks can adjust their interest rates faster than their costs increase, thus impacting positively on profitability. But where inflation is not anticipated, costs increase faster than any adjustment in interest rates so there is a negative impact on profitability. Therefore, some studies find the link to be positive (Athanasoglou et al., 2008; Trujillo-Ponce, 2013), while others find it to be negative (Naceur and Omran, 2011).

Two hypotheses are proposed to explain how the degree of sector concentration influences bank profitability. The structure-conduct-performance (SCP) hypothesis states that a more concentrated sector favours higher profitability motivated by greater market power, whereas the efficient-structure (ES) hypothesis argues that higher efficiency enables efficient banks to gain more of a market share and thus generate higher profits. Although both hypotheses suggest the link between concentration and profitability to be positive, the empirical evidence is again not conclusive, with some studies finding a positive impact (Claeys and Vander Vennet, 2008; Goddard et al., 2004b; Maudos and De Guevara, 2004), and others a negative one (Naceur and Omran, 2011).

However, overwhelmingly the literature considers the effect of internal and external determinants of bank profitability for developed and developing countries while the states 
that comprised the former USSR have not been extensively explored. The literature review has shown that while the variables used are common to many studies, the direction of the impact is not consistent across countries. Moreover, only a limited number of studies take into account the effect of institutions and of economic freedom, as defined by the Heritage Foundation, on bank profitability (Sufian and Habibullah, 2010), and none consider these factors in transition countries. Thus, this paper fills this gap in the literature by exploring early and late transition countries using the most recent data (2000-2013), and including economic freedom variables from the Heritage Foundation.

In any study of the role of banks in developing and transition countries, regulations and the quality of supervision are vitally important. The aspects of governance perform two major functions, that is to safeguard the soundness of the financial sector, and ensure that banks meet basic fiduciary responsibilities. Both only succeed if the level of state involvement does not become so large that it threatens the sustainability of banking growth by introducing inefficiency and by increasing corruption.

Table 2 reports indices for three groups of countries. These measure fiscal freedom, government spending and monetary independence, all of which may have a significant impact on bank performance. These indices range from 0 to 100 , where 100 implies high economic freedom. Fiscal freedom is a measure of the tax burden imposed by the government, where a higher score indicates less burden imposed by fiscal policy. Higher scores for government spending and monetary policy imply the presence of their being less burden imposed by government expenditures, and higher price stability in the absence of state intervention, respectively.

Table 2 shows that the fiscal burden and government spending are lower in late transition countries compared to the early transition ones. However, higher price stability is 
present in early transition countries. The third group in Table 2 are developed countries, which are considered to be laissez faire economies according to the Heritage Foundation. Comparing these three groups shows that there is a clear trend, and as economies grow the fiscal burden and government spending increases and price stability improves. As the optimal level of economic freedom varies across countries, it is interesting to note the impact on banking profitability as a factor in determining policy relating to the future strategic development of the sector.

Table 2. Economic Freedom Variables

\begin{tabular}{|c|c|c|c|c|}
\hline Countries & year & $\begin{array}{c}\text { Fiscal } \\
\text { freedom }\end{array}$ & $\begin{array}{l}\text { Government } \\
\text { spending }\end{array}$ & $\begin{array}{l}\text { Monetary } \\
\text { freedom }\end{array}$ \\
\hline \multicolumn{5}{|c|}{ Late transition countries } \\
\hline Armenia & 2013 & 88.00 & 82.10 & 73.00 \\
\hline Azerbaijan & 2013 & 85.50 & 67.80 & 73.50 \\
\hline Belarus & 2013 & 88.80 & 43.50 & 40.70 \\
\hline Georgia & 2013 & 88.20 & 68.90 & 72.60 \\
\hline Kazakhstan & 2013 & 93.20 & 84.50 & 72.20 \\
\hline Moldova & 2013 & 87.20 & 50.10 & 73.40 \\
\hline Ukraine & 2013 & 78.20 & 29.40 & 71.00 \\
\hline Uzbekistan & 2013 & 90.20 & 67.80 & 63.00 \\
\hline Average & & 87.41 & 61.76 & 67.43 \\
\hline \multicolumn{5}{|c|}{ Early transition countries } \\
\hline Czech Rep & 2013 & 82.00 & 43.50 & 81.70 \\
\hline Estonia & 2013 & 79.70 & 56.20 & 77.10 \\
\hline Hungary & 2013 & 79.70 & 29.70 & 77.10 \\
\hline Latvia & 2013 & 84.40 & 53.60 & 78.30 \\
\hline Lithuania & 2013 & 92.80 & 53.60 & 78.30 \\
\hline Poland & 2013 & 76.00 & 43.00 & 77.70 \\
\hline Slovakia & 2013 & 84.70 & 58.00 & 79.10 \\
\hline Slovenia & 2013 & 65.70 & 22.30 & 81.60 \\
\hline Average & & 80.63 & 44.99 & 78.86 \\
\hline \multicolumn{5}{|c|}{ Developed countries } \\
\hline Austria & 2013 & 51.10 & 23.50 & 79.30 \\
\hline Canada & 2013 & 79.80 & 44.80 & 75.20 \\
\hline Denmark & 2013 & 39.80 & $\begin{array}{l}44.00 \\
5.90\end{array}$ & 80.00 \\
\hline France & 2013 & 53.00 & 5.60 & 81.10 \\
\hline Germany & 2013 & 61.80 & 37.30 & 81.20 \\
\hline Japan & 2013 & 69.20 & 45.00 & 90.60 \\
\hline The & 2013 & 52.10 & 24.70 & 81.10 \\
\hline United & 2013 & 57.00 & 27.70 & 72.40 \\
\hline United States & 2013 & 69.30 & 47.80 & 75.00 \\
\hline Average & & 59.23 & 29.14 & 79.54 \\
\hline
\end{tabular}

Although early transition countries have taken a relatively fast approach to transition and have become members of the EU, both groups of transition countries have undergone significant changes in state, fiscal and monetary policies. Governments have led reform programmes to drive the economic transformation in CEE since the end of the 1980's, and in the former Soviet Union transition countries since the beginning of the 1990's. There are 
many channels through which the state can influence firm and sector level growth. Particularly, governments have a significant influence over the establishment of an environment that enables new firms to develop and grow. Thus, the first testable hypothesis is as follows:

Hypothesis 1: Government spending has an impact on bank profitability.

The second channel by which governments impact on firm growth is fiscal policy. In transition countries, where the institutions are still relatively weak and legislation changes quickly, the significant tax burden encourages entrepreneurs to move into the informal and shadow economy (Smallbone and Welter, 2001). Thus, the second testable hypothesis is as follows:

Hypothesis 2: Fiscal freedom has an impact on bank profitability.

Governments, particularly those of late transition countries, influence the sustainability of banking growth through reforms that address the development of economic institutions such as central banks and other financial institutions, which are responsible for monetary policy, price stability and interest rates (Smallbone and Welter, 2001). As the banks of the former USSR states generate revenue largely from conventional banking, their profitability may be influenced by price stability, changes in money supply and interest rates. Therefore, the final testable hypothesis is as follows:

Hypothesis 3: Monetary freedom has an impact on bank profitability.

\subsection{Variable selection}

Table 3 lists the variables used in the study. Following the literature, return on assets (ROA) is the dependent variable, This is the profit earned per dollar of assets, and reflects the ability of management to utilise the bank resources to generate profits (Athanasoglou et al., 2008; 
Dietrich and Wanzenried, 2011; Flamini et al., 2009; Sufian and Habibullah, 2010). This was chosen in preference to return on equity (ROE), as the latter disregards financial leverage and the risks associated with that (Flamini et al., 2009). ROA may be biased due to off-balancesheet activities, but this is expected to be negligible in the case of transition countries.

Table 3. Variables used in the estimation

\begin{tabular}{|c|c|c|c|c|}
\hline Variables & Description & \multicolumn{2}{|l|}{ Source } & $\begin{array}{l}\text { Expected } \\
\text { effect }\end{array}$ \\
\hline \multicolumn{5}{|l|}{ Dependent variable: } \\
\hline \multicolumn{5}{|l|}{ Independent variables: } \\
\hline Capital & Equity/total assets & \multicolumn{2}{|c|}{ Bankscope } & + \\
\hline Credit risk & Loan loss provisions/loans & \multicolumn{2}{|c|}{ Bankscope } & - \\
\hline Cost & $\begin{array}{l}\text { Total costlpre-tax profit } \\
\text { (total cost includes overheads and interest expenses) }\end{array}$ & \multicolumn{2}{|c|}{ Bankscope } & - \\
\hline Size & Logarithm of total assets & \multicolumn{2}{|c|}{ Bankscope } & + \\
\hline HHI & Squared sum of bank market share & \multicolumn{2}{|c|}{ Bankscope } & + \\
\hline GDP growth & Annual GDP growth & \multirow{2}{*}{\multicolumn{2}{|c|}{$\begin{array}{l}\text { World Bank's World } \\
\text { Development Indicators } \\
\text { (2014) }\end{array}$}} & + \\
\hline Inflation & Annual changes in Consumer Price Index (CPI) & & & $+/-$ \\
\hline Government spending & $\begin{array}{l}\text { A high score indicates less burden imposed by } \\
\text { government expenditures (score ranges between } 0 \text { and } \\
\text { 100) }\end{array}$ & $\begin{array}{l}\text { Heritage } \\
(2014)\end{array}$ & Foundation & $-/+$ \\
\hline Fiscal freedom & $\begin{array}{l}\text { Fiscal freedom is a measure of the tax burden imposed } \\
\text { by the government. A high score indicates less burden } \\
\text { imposed by fiscal policy (score ranges between } 0 \text { and } \\
\text { 100) }\end{array}$ & $\begin{array}{l}\text { Heritage } \\
(2014)\end{array}$ & Foundation & $-/+$ \\
\hline Monetary freedom & $\begin{array}{l}\text { A high score indicates greater price stability without } \\
\text { microeconomic intervention (score ranges between } 0 \\
\text { and 100) }\end{array}$ & $\begin{array}{l}\text { Heritage } \\
(2014)\end{array}$ & Foundation & $-/+$ \\
\hline
\end{tabular}

The loan loss provisions to loans ratio is used to proxy credit risk. The effect on profitability is expected to be negative as increased exposure to credit risk is associated with decreased bank profitability. The equity to total assets ratio is used to proxy Capital. This is expected to have a positive impact, given this represents the amount of bank funds available to support business operations, and therefore acts as a safety net in the case of adverse developments (Athanasoglou et al., 2008). Moreover, increases in capital may provide a good signal of better future prospects for the bank. Cost (or operating costs) is defined as the ratio of total cost (overheads and interest expenses) to pre-tax profit. This measures the impact of 
operating efficiency on bank profitability and therefore is expected to negatively affect bank profitability.

Although, as noted in the literature review, some studies do not find a significant size impact on bank profitability, here scale economies and wider product diversity are expected to show that larger banks have higher profitability, particularly in these transition countries. To include information for all the banks, a concentration variable $H H I$ was calculated. This is the sum of the squares of the market shares of all banks with the industry, following (Dietrich and Wanzenried, 2011). This is expected to have a positive impact on bank profitability, as claimed by the structure-conduct-performance hypothesis.

Higher GDP growth increases the demand for lending and thus its impact is expected to be positive. However, if managers anticipate inflation and reflect it in interest rates the effect is positive, otherwise it is negative. The Heritage Foundation's economic freedom variables, such as government spending, fiscal policy and monetary freedom may affect bank profitability with different signs. There is no optimal size of government spending and may vary between countries, although the impact is likely to be different. However, excessive government spending and debt are detrimental to the performance of the financial sector. Thus, too much or too little government spending may negatively impact on profitability, while a moderate level is expected to influence positively. Additionally, very high or very low levels of government spending, as well as fiscal and monetary freedom, may impact negatively when the institutions and national governance that are intended to support the financial sector are relatively weak.

\section{Data and Methods}

The banking sectors of transition countries have undergone significant changes over the last two decades. Particularly, reforms have been pursued to support the further improvements of 
the institutional framework, and the more efficient functioning of banks as well in order to attract Western banks to enter their markets. This has created a new and more sophisticated banking environment with higher degrees of competition. Thus, the econometric modelling of bank profitability must take account of the different levels of complexity in this sample and the characteristics of the data available. .

\subsection{Specification of bank profitability model}

Following the literature, the general model to be estimated is a one-way error component linear regression model (Athanasoglou et al., 2008; Dietrich and Wanzenried, 2011):

$$
\mathrm{ROA}_{\mathrm{it}}=\mathrm{c}+\delta \mathrm{ROA}_{\mathrm{i}, \mathrm{t}-1}+\sum_{j=1}^{J} \beta_{j} X_{\mathrm{it}}^{j}+\sum_{\mathrm{l}=1}^{L} \beta_{1} X_{\mathrm{it}}^{\mathrm{Q}}+\sum_{m=1}^{M} \beta_{\mathrm{m}} X_{\mathrm{it}}^{\mathrm{m}}+\sum_{N=1}^{\mathrm{N}} \beta_{1} X_{\mathrm{it}}^{\mathrm{n}}+\sum_{\mathrm{n}=1}^{\mathrm{W}} \beta_{\mathrm{n}} X_{\mathrm{it}}^{\mathrm{n}}+\varepsilon_{\mathrm{it}}
$$

where $\mathrm{ROA}_{\mathrm{it}}$ is a return on the assets of bank $i$ at time $t$ with $i=1, \ldots, \mathrm{N}, t=1, \ldots, \mathrm{T}, \mathrm{c}$ is a constant term. The $X_{i t}$ 's are bank-specific, market-specific, macroeconomic and institutionalenvironmental variables and $\varepsilon_{i t}$ is the disturbance term, with $\mathrm{v}_{\mathrm{i}}$ the unobserved bank-specific effect and $\mathrm{u}_{\mathrm{it}}$ the idiosyncratic error. In this model $\mathrm{v}_{\mathrm{i}} \sim\left(\mathrm{IIN}\left(0,0, \sigma_{v}^{2}\right)\right)$ and is independent of the $\mathrm{u}_{\mathrm{it}} \sim\left(\mathrm{IIN}\left(0, \sigma_{\mathrm{u}}^{2}\right)\right)$. Recent studies find that bank profits are inclined to persist over time, reflecting impediments to market competition, informational opacity and/or sensitivity to regional-macroeconomic shocks, especially as these effects are serially correlated (Berger et al., 2000). Therefore, in this paper, a lagged dependent variable is included to capture this phenomenon, such that $\mathrm{ROA}_{\mathrm{i}, \mathrm{t}-1}$ is a one-period lagged variable and $\delta$ the speed of adjustment to equilibrium. $\delta$ takes a value between 0 and 1, implying that profits eventually return to equilibrium. A value of $\delta$ close to 0 shows that the industry is competitive, whilst a value close to 1 suggests lower levels of competition.

Least squares estimators can produce biased and inconsistent coefficients for dynamic models (Baltagi, 2008; Bond, 2002). In addition, models to estimate bank profitability may 
be subject to endogeneity. Many empirical studies find that more profitable banks can increase their equity using retained earnings (García-Herrero et al., 2009) and have more extensive marketing budgets, which in turn result in increased expansion and then larger banks become more profitable. However, more profitable banks can increase their personnel expenses, such as higher consultancy fees, thus reducing their operational efficiency. This suggests that the causality between size and profitability could go in the opposite direction. Finally, unobservable heterogeneity between banks, for example, differences in the quality of corporate governance, can also impact on bank profitability.

To address these issues, the generalised method of moments (GMM) is used in the estimation, following the approach by Arellano and Bover (Arellano and Bover, 1995). The system GMM estimator uses lagged values of a dependent variable in the levels, and in differences in instruments as well as lagged values of other independent variables, which could potentially suffer from endogeneity. The system GMM has the advantage of minimising the data loss for unbalanced panels by transforming the data with forwardorthogonal deviations (Arellano and Bover, 1995; Roodman, 2009). In addition, the GMM estimator controls for unobserved heterogeneity. As a robustness check the models were also estimated using a random-effects approach for the same model specification (equation 1).

\subsection{Data}

The sample consists of 275 banks from 16 transition economies. Eight are from the former Soviet Union and are considered to be the late transition group. These are: Armenia, Azerbaijan, Belarus, Georgia, Kazakhstan, Moldova, Ukraine and Uzbekistan. The remaining countries are from the CEE and the Baltic States, and are considered to be the early transition group. These are: Czech Republic, Estonia, Hungary, Latvia, Lithuania, Poland, Slovak Republic and Slovenia. The data are from Bankscope and are an unbalanced 
panel. All are commercial banks whose financial statements are available for at least three years over the period 2000-2013. All the bank relevant data are in US dollars at a current exchange rate. The statistics for the growth of GDP and inflation are from the World Bank World Development Indicators (2014). The institutional-environmental variables of economic freedom are from the Heritage Foundation.

\section{Empirical results}

Table 4 reports the cross-correlation matrix of independent variables. This indicates that there is a relatively high level of correlation between government spending, fiscal freedom and monetary freedom variables. Therefore, only one of the economic freedom variables are included in the regression at a time.

Table 4. Cross-correlation matrix of independent variables

\begin{tabular}{|c|c|c|c|c|c|c|c|}
\hline \multirow[t]{2}{*}{ Variables } & \multicolumn{7}{|c|}{ Late transition countries } \\
\hline & Mean & HHI & GDP growth & Inflation & $\begin{array}{l}\text { Government } \\
\text { Spending }\end{array}$ & $\begin{array}{l}\text { Fiscal } \\
\text { freedom }\end{array}$ & $\begin{array}{l}\text { Monetary } \\
\text { freedom }\end{array}$ \\
\hline $\mathrm{HHI}$ & 0.228 & 1.000 & & & & & \\
\hline GDP growth & 1.695 & $0.152 * * *$ & 1.000 & & & & \\
\hline Inflation & 2.324 & $0.142 * * *$ & -0.010 & 1.000 & & & \\
\hline Government Spending & 68,624 & $-0.114 * * *$ & $0.325 * * *$ & $-0.216^{* * *} *$ & 1.000 & & \\
\hline Fiscal freedom & 83,151 & $-0.418 * * *$ & -0.010 & $-0.259 * * *$ & $0.268 * * *$ & 1.000 & \\
\hline \multirow[t]{2}{*}{ Monetary freedom } & 69.023 & $-0.328 * * *$ & $0.113 * * *$ & $-0.418 * * *$ & $0.466 * * *$ & $0.379 * * *$ & 1.000 \\
\hline & \multicolumn{7}{|c|}{ Early transition countries } \\
\hline HHI & 0.220 & 1.000 & & & & & \\
\hline GDP growth & 1.284 & $0.135^{* * *} *$ & 1.000 & & & & \\
\hline Inflation & 1.086 & $0.127 * * *$ & $0.176^{* * *}$ & 1.000 & & & \\
\hline Government Spending & 43.600 & $0.195 * * *$ & $0.327 * * *$ & $0.107 * * *$ & 1.000 & & \\
\hline Fiscal freedom & 72.882 & -0.022 & $0.195 * * *$ & $-0.088 * * *$ & $0.548^{* * * *}$ & 1.000 & \\
\hline Monetary freedom & 78.349 & 0.048 & 0.278 & $-0.328 * * *$ & $0.200 * * *$ & $0.200 * * *$ & 1.000 \\
\hline
\end{tabular}

Correlations that are significantly different from zero at the $1 \%, 5 \%$ and $10 \%$ level are marked with $* * *, * *$ and $*$ respectively. GDP growth and inflation are in natural logarithm forms.

Because of the unbalanced panel, Fisher's unit root test is used as a suitable approach to test the stationary of the variables (Choi, 2001; Maddala and $\mathrm{Wu}, 1999)$. The test results show that all the variables used are stationary (see Table 5). 
Table 5. Fisher's Unit Root test

\begin{tabular}{|c|c|c|c|c|c|}
\hline \multirow[t]{2}{*}{ Variables } & \multicolumn{5}{|c|}{ Late transition countries } \\
\hline & lags & $\mathrm{P}$ & $\mathrm{Z}$ & $\mathrm{L}^{*}$ & $\mathrm{Pm}$ \\
\hline ROA & 1 & $691.50(0.00)$ & $-13.60(0.00)$ & $-17.63(0.00)$ & $18.29(0.00)$ \\
\hline Capital & 1 & $633.35(0.00)$ & $-7.40(0.00)$ & $-12.83(0.00)$ & $15.78(0.00)$ \\
\hline Credit risk & 1 & $747.92(0.00)$ & $-13.55(0.00)$ & $-19.55(0.00)$ & $21.91(0.00)$ \\
\hline Cost & 1 & $430.98(0.00)$ & $-2.15(0.02)$ & $-4.62(0.00)$ & $7.15(0.00)$ \\
\hline Size & 1 & $570.66(0.00)$ & $-2.11(0.02)$ & $-7.83(0.00)$ & $13.07(0.00)$ \\
\hline HHI & 1 & $782.81(0.00)$ & $-2.92(0.00)$ & $-11.62(0.00)$ & $22.24(0.00)$ \\
\hline GDP growth & 1 & $1422.97(0.00)$ & $-22.62(0.00)$ & $-42.96(0.00)$ & $52.16(0.00)$ \\
\hline Inflation & 1 & $432.49(0.00)$ & $-4.89(0.00)$ & $-8.90(0.00)$ & $7.68(0.00)$ \\
\hline Government spending & 1 & $430.20(0.00)$ & $-2.69(0.00)$ & $-5.75(0.00)$ & $7.01(0.00)$ \\
\hline Government spending ${ }^{2}$ & 1 & $427.64(0.00)$ & $-2.88(0.00)$ & $-5.72(0.00)$ & $6.90(0.00)$ \\
\hline Fiscal freedom & 1 & $803.17(0.00)$ & $-9.84(0.00)$ & $-18.11(0.00)$ & $23.11(0.00)$ \\
\hline Fiscal freedom ${ }^{2}$ & 1 & $696.42(0.00)$ & $-8.61(0.00)$ & $-14.83(0.00)$ & $18.50(0.00)$ \\
\hline Monetary freedom & 1 & $695.06(0.00)$ & $-6.73(0.00)$ & $-11.72(0.00)$ & $18.45(0.00)$ \\
\hline Monetary freedom ${ }^{2}$ & 1 & $537.41(0.00)$ & $-4.00(0.00)$ & $-7.68(0.00)$ & $11.64(0.00)$ \\
\hline Variables & \multicolumn{5}{|c|}{ Early transition countries } \\
\hline ROA & 1 & $520.61(0.00)$ & $-8.95(0.00)$ & $-10.98(0.00)$ & $10.91(0.00)$ \\
\hline Capital & 1 & $499.96(0.00)$ & $-4.51(0.00)$ & $-6.98(0.00)$ & $9.77(0.00)$ \\
\hline Credit risk & 1 & $334.17(0.00)$ & $-0.60(0.28)$ & $-3.20(0.00)$ & $4.30(0.00)$ \\
\hline Cost & 1 & $327.73(0.01)$ & $-1.38(0.08)$ & $-3.35(0.00)$ & $2.67(0.00)$ \\
\hline Size & 1 & $382.90(0.00)$ & $0.01(0.49)$ & $-2.85(0.00)$ & $4.75(0.00)$ \\
\hline HHI & 1 & $657.23(0.00)$ & $-6.32(0.00)$ & $-11.79(0.00)$ & $16.37(0.00)$ \\
\hline GDP growth & 1 & $461.48(0.00)$ & $-2.04(0.02)$ & $-6.15(0.00)$ & $9.85(0.00)$ \\
\hline Inflation & 1 & $572.37(0.00)$ & $-8.35(0.00)$ & $-12.96(0.00)$ & $13.70(0.00)$ \\
\hline Government spending & 1 & $619.83(0.00)$ & $-9.36(0.00)$ & $-13.45(0.00)$ & $14.77(0.00)$ \\
\hline Government spending 2 & 1 & $695.20(0.00)$ & $-9.54(0.00)$ & $-15.00(0.00)$ & $17.99(0.00)$ \\
\hline Fiscal freedom & 1 & $373.59(0.00)$ & $-2.26(0.01)$ & $-3.90(0.00)$ & $4.25(0.00)$ \\
\hline Fiscal freedom ${ }^{2}$ & 1 & $648.12(0.00)$ & $-7.14(0.00)$ & $-11.71(0.00)$ & $15.98(0.00)$ \\
\hline Monetary freedom & 1 & $502.40(0.00)$ & $-1.52(0.06)$ & $-4.58(0.00)$ & $9.76(0.00)$ \\
\hline Monetary freedom ${ }^{2}$ & 1 & $475.64(0.00)$ & $-1.33(0.09)$ & $-4.08(0.00)$ & $8.61(0.00)$ \\
\hline
\end{tabular}

Table 6. System GMM results (late transition countries)

\begin{tabular}{|c|c|c|c|c|c|c|c|}
\hline Variables & (1) & (2) & (3) & (4) & (5) & (6) & (7) \\
\hline \multirow[t]{2}{*}{ L.ROA } & $0.692 * * *$ & $0.684 * * *$ & $0.686^{* * *}$ & $0.685 * * *$ & $0.684 * * *$ & $0.689 * * *$ & $0.690 * * *$ \\
\hline & $(0.172)$ & $(0.172)$ & $(0.172)$ & $(0.173)$ & $(0.173)$ & $(0.165)$ & $(0.166)$ \\
\hline \multirow[t]{2}{*}{ Capital } & 2.991 & 3.154 & 3.116 & 3.201 & 3.211 & 3.113 & 3.066 \\
\hline & $(2.287)$ & $(2.313)$ & $(2.301)$ & $(2.355)$ & $(2.362)$ & $(2.222)$ & $(2.219)$ \\
\hline \multirow[t]{2}{*}{ Credit risk } & $-5.853 * * *$ & $-5.826 * * *$ & $-5.824 * * *$ & $-5.884 * * *$ & $-5.871 * * *$ & $-5.933 * * *$ & $-5.907 * * *$ \\
\hline & $(0.204)$ & $(0.200)$ & $(0.199)$ & $(0.180)$ & $(0.190)$ & $(0.168)$ & $(0.172)$ \\
\hline \multirow[t]{2}{*}{ Cost } & -0.008 & -0.008 & -0.008 & -0.008 & -0.008 & -0.007 & -0.008 \\
\hline & $(0.008)$ & $(0.007)$ & $(0.007)$ & $(0.008)$ & $(0.007)$ & $(0.008)$ & $(0.008)$ \\
\hline \multirow[t]{2}{*}{ Size } & -0.004 & 0.141 & 0.099 & 0.183 & 0.170 & $0.191 * *$ & $0.141^{*}$ \\
\hline & $(0.072)$ & $(0.095)$ & $(0.074)$ & $(0.128)$ & $(0.115)$ & $(0.089)$ & $(0.081)$ \\
\hline \multirow[t]{2}{*}{ HHI } & 0.740 & 0.577 & 0.434 & 1.274 & 1.063 & 1.111 & 0.956 \\
\hline & (1.007) & $(0.879)$ & $(0.808)$ & (1.107) & (1.024) & $(0.933)$ & $(0.954)$ \\
\hline \multirow[t]{2}{*}{ GDP growth } & -0.017 & 0.037 & 0.020 & 0.041 & 0.043 & 0.014 & 0.015 \\
\hline & (0.069) & $(0.051)$ & (0.059) & $(0.049)$ & $(0.047)$ & $(0.032)$ & $(0.031)$ \\
\hline \multirow[t]{2}{*}{ L.GDP growth } & -0.156 & -0.104 & -0.114 & -0.097 & -0.100 & -0.081 & -0.083 \\
\hline & $(0.118)$ & $(0.088)$ & $(0.091)$ & $(0.094)$ & $(0.091)$ & $(0.091)$ & $(0.091)$ \\
\hline \multirow[t]{2}{*}{ Inflation } & 0.092 & 0.010 & 0.032 & 0.042 & 0.039 & -0.003 & -0.010 \\
\hline & $(0.079)$ & $(0.047)$ & $(0.048)$ & $(0.059)$ & $(0.055)$ & $(0.053)$ & $(0.055)$ \\
\hline \multirow{2}{*}{ L.Inflation } & -0.224 & -0.280 & -0.310 & -0.147 & -0.185 & -0.247 & -0.251 \\
\hline & $(0.243)$ & $(0.246)$ & $(0.267)$ & $(0.182)$ & $(0.206)$ & $(0.231)$ & $(0.230)$ \\
\hline Government spending & & $-0.013 *$ & & & & & \\
\hline \multirow[t]{2}{*}{ Government spending ${ }^{2}$} & & $(0.007)$ & $-0.000 *$ & & & & \\
\hline & & & $(0.000)$ & & & & \\
\hline \multirow[t]{2}{*}{ Fiscal freedom } & & & & $-0.019 *$ & & & \\
\hline & & & & $(0.011)$ & & & \\
\hline \multirow[t]{2}{*}{ Fiscal freedom $^{2}$} & & & & & $-0.000 *$ & & \\
\hline & & & & & $(0.000)$ & & \\
\hline nonetary rreedom & & & & & & $\begin{array}{c}-0.018 \cdots \cdots * \\
(0.006)\end{array}$ & \\
\hline Monetary freedom $^{2}$ & & & & & & & $\begin{array}{c}-0.000 * * \\
(0.000)\end{array}$ \\
\hline Number of instruments & 125 & 126 & 126 & 126 & 126 & 126 & 126 \\
\hline Sargan-test & $\chi^{2}(104)=665.50$ & $\chi^{2}(104)=665.50$ & $\chi^{2}(104)=665.50$ & $\chi^{2}(104)=665.50$ & $\chi^{2}(104)=665.50$ & $\chi^{2}(104)=665.50$ & $\chi^{2}(104)=665.50$ \\
\hline $\mathrm{AB}$ test $\mathrm{AR}(1)$ (p-value) & $(0.222)$ & $(0.235)$ & $(0.230)$ & $(0.231)$ & $(0.238)$ & $(0.235)$ & $(0.224)$ \\
\hline $\mathrm{AB}$ test $\mathrm{AR}(2)(\mathrm{p}$-value $)$ & $(0.236)$ & $(0.319)$ & $(0.318)$ & $(0.327)$ & $(0.327)$ & $0.326)$ & $(0.323)$ \\
\hline Observations & 879 & 879 & 879 & 879 & 879 & 879 & 879 \\
\hline Number of banks & 146 & 146 & 146 & 146 & 146 & 146 & 146 \\
\hline
\end{tabular}

Robust standard errors are in brackets. Coefficients that are significantly different from zero at the 1\%, 5\% and $10 \%$ level are marked with $* * *, * *$ and $*$ respectively. Year dummies for 2000-2010 are removed to save space. Bank-specific variables (italicised) are treated as endogenous variables. 
Tables $6,7,8$ and 9 summarise the estimation results. In particular, tables 6 and 7 show the results from the system dynamic panel, and tables 8 and 9 the random-effects panel models for the late and early transition countries, respectively. The Sargan test estimation results in Tables 6 and 7 point to the absence of over-identifying restrictions. The ArellanoBond $(\mathrm{AB})$ tests show the absence of first- and second-order autocorrelation.

The coefficients on the lagged dependent variable (ROA) are between 0 and 1 implying that bank profitability persists over time. However, the coefficients are closer to 1 in late transition countries and closer to 0 in early transition ones, suggesting that early transition countries have more competitive banking sectors, as expected.

Table 7. System GMM results (early transition countries)

\begin{tabular}{|c|c|c|c|c|c|c|c|}
\hline Variables & $(1)$ & $(2)$ & (3) & $(4)$ & $(5)$ & $(6)$ & $(7)$ \\
\hline L.ROA & $\begin{array}{c}0.058 * * * \\
(0.006)\end{array}$ & $\begin{array}{c}0.057 * * * \\
(0.006)\end{array}$ & $\begin{array}{c}0.058 * * * \\
(0.006)\end{array}$ & $\begin{array}{c}0.058 * * * \\
(0.005)\end{array}$ & $\begin{array}{c}0.058 * * * \\
(0.006)\end{array}$ & $\begin{array}{c}0.060^{* * * *} \\
(0.005)\end{array}$ & $\begin{array}{c}0.058 * * * \\
(0.005)\end{array}$ \\
\hline Capital & $\begin{array}{c}18.032 * * * \\
(0.330)\end{array}$ & $\begin{array}{c}17.992 * * * \\
(0.313)\end{array}$ & $\begin{array}{c}18.035 * * * \\
(0.325)\end{array}$ & $\begin{array}{c}18.030 * * * \\
(0.374)\end{array}$ & $\begin{array}{c}17.954 * * * \\
(0.305)\end{array}$ & $\begin{array}{c}18.398 * * * \\
(0.967)\end{array}$ & $\begin{array}{c}17.829 * * * \\
(1.086)\end{array}$ \\
\hline Credit risk & $\begin{array}{c}26.541 * * * \\
(5.306)\end{array}$ & $\begin{array}{c}26.329 * * * \\
(5.405)\end{array}$ & $\begin{array}{c}26.463 * * * \\
(5.593)\end{array}$ & $\begin{array}{c}26.993 * * * \\
(4.591)\end{array}$ & $\begin{array}{c}26.574 * * * \\
(5.309)\end{array}$ & $\begin{array}{c}27.790 * * * \\
(4.144)\end{array}$ & $\begin{array}{c}27.352 * * * \\
(4.452)\end{array}$ \\
\hline Cost & $\begin{array}{c}0.008 \\
(0.009)\end{array}$ & $\begin{array}{c}0.009 \\
(0.011)\end{array}$ & $\begin{array}{c}0.008 \\
(0.009)\end{array}$ & $\begin{array}{c}0.008 \\
(0.014)\end{array}$ & $\begin{array}{c}0.009 \\
(0.010)\end{array}$ & $\begin{array}{c}0.006 \\
(0.012)\end{array}$ & $\begin{array}{c}0.008 \\
(0.012)\end{array}$ \\
\hline Size & $\begin{array}{c}-0.312 * * * \\
(0.058)\end{array}$ & $\begin{array}{c}-0.331 * * * \\
(0.111)\end{array}$ & $\begin{array}{c}-0.325 * * * \\
(0.064)\end{array}$ & $\begin{array}{l}-0.277 \\
(0.314)\end{array}$ & $\begin{array}{c}-0.349 * * * \\
(0.123)\end{array}$ & $\begin{array}{l}-0.061 \\
(0.613)\end{array}$ & $\begin{array}{l}-0.382 \\
(0.575)\end{array}$ \\
\hline HHI & $\begin{array}{c}0.066 \\
(0.993)\end{array}$ & $\begin{array}{l}-0.458 \\
(0.937)\end{array}$ & $\begin{array}{l}-0.264 \\
(1.030)\end{array}$ & $\begin{array}{c}-0.375 \\
(1.143)\end{array}$ & $\begin{array}{l}-0.610 \\
(0.905)\end{array}$ & $\begin{array}{l}-0.006 \\
(1.471)\end{array}$ & $\begin{array}{l}-0.658 \\
(1.321)\end{array}$ \\
\hline GDP growth & $\begin{array}{c}0.111 \\
(0.166)\end{array}$ & $\begin{array}{c}0.038 \\
(0.138)\end{array}$ & $\begin{array}{c}0.053 \\
(0.145)\end{array}$ & $\begin{array}{c}0.127 \\
(0.181)\end{array}$ & $\begin{array}{c}0.060 \\
(0.180)\end{array}$ & $\begin{array}{c}0.161 \\
(0.159)\end{array}$ & $\begin{array}{c}0.084 \\
(0.203)\end{array}$ \\
\hline L.GDP growth & $\begin{array}{c}0.024 \\
(0.113)\end{array}$ & $\begin{array}{l}-0.041 \\
(0.134)\end{array}$ & $\begin{array}{l}-0.026 \\
(0.125)\end{array}$ & $\begin{array}{l}-0.031 \\
(0.141)\end{array}$ & $\begin{array}{l}-0.073 \\
(0.122)\end{array}$ & $\begin{array}{c}0.022 \\
(0.169)\end{array}$ & $\begin{array}{l}-0.085 \\
(0.258)\end{array}$ \\
\hline Inflation & $\begin{array}{l}-0.122 \\
(0.105)\end{array}$ & $\begin{array}{l}-0.135 \\
(0.120)\end{array}$ & $\begin{array}{l}-0.130 \\
(0.113)\end{array}$ & $\begin{array}{l}-0.130 \\
(0.135)\end{array}$ & $\begin{array}{l}-0.133 \\
(0.109)\end{array}$ & $\begin{array}{l}-0.106 \\
(0.135)\end{array}$ & $\begin{array}{l}-0.113 \\
(0.095)\end{array}$ \\
\hline L.Inflation & $\begin{array}{l}-0.146 \\
(0.130)\end{array}$ & $\begin{array}{l}-0.182 \\
(0.138)\end{array}$ & $\begin{array}{l}-0.159 \\
(0.135)\end{array}$ & $\begin{array}{l}-0.206 \\
(0.165)\end{array}$ & $\begin{array}{l}-0.224^{*} \\
(0.135)\end{array}$ & $\begin{array}{l}-0.213^{*} \\
(0.113)\end{array}$ & $\begin{array}{l}-0.170 \\
(0.166)\end{array}$ \\
\hline Government spending & & $\begin{array}{c}0.010 \\
(0.019)\end{array}$ & & & & & \\
\hline Government spending ${ }^{2}$ & & & $\begin{array}{c}0.000 \\
(0.000)\end{array}$ & & & & \\
\hline Fiscal freedom & & & & $\begin{array}{l}-0.001 \\
(0.037)\end{array}$ & & & \\
\hline Fiscal freedom ${ }^{2}$ & & & & & $\begin{array}{c}0.000 \\
(0.000)\end{array}$ & & \\
\hline Monetary freedom & & & & & & $\begin{array}{l}-0.025 \\
(0.069)\end{array}$ & \\
\hline Monetary freedom $^{2}$ & & & & & & & $\begin{array}{c}0.000 \\
(0.001)\end{array}$ \\
\hline Number of instruments & 30 & 31 & 31 & 31 & 31 & 31 & 31 \\
\hline Sargan-test & $\chi^{2}(9)=24.81$ & $\chi^{2}(9)=25.60$ & $\chi^{2}(9)=26.31$ & $\chi^{2}(9)=24.86$ & $\chi^{2}(9)=25.23$ & $\chi^{2}(9)=27.18$ & $\chi^{2}(9)=25.21$ \\
\hline $\mathrm{AB}$ test $\mathrm{AR}(1)$ (p-value) & $(0.293)$ & $(0.341)$ & $(0.308)$ & $(0.475)$ & $(0.238)$ & $(0.470)$ & $(0.402)$ \\
\hline $\mathrm{AB}$ test $\mathrm{AR}(2)$ (p-value) & $(0.349)$ & $(0.319)$ & $(0.328)$ & $(0.412)$ & $(0.320)$ & $0.468)$ & $(0.367)$ \\
\hline Observations & 743 & 743 & 743 & 743 & 743 & 743 & 743 \\
\hline Number of banks & 129 & 129 & 129 & 129 & 129 & 129 & 129 \\
\hline
\end{tabular}

Robust standard errors are in brackets. Coefficients that are significantly different from zero at the 1\%, 5\% and $10 \%$ level are marked with $* * *, * *$ and $*$ respectively. Year dummies for 2000-2010 are removed to save space. Bank-specific variables (italicised) are treated as endogenous variables. 
The coefficients on Capital are positive and significant in tables 7 and 9, implying that better capitalised banks are more profitable in early transition countries. However, this is not the case for late transition countries as this variable is not significantly different from zero in both sets of models (tables 6 and 8). This is consistent with the literature and supports the view that early transition countries have more sound financial conditions. These banks can pursue business opportunities more effectively and have more flexibility in dealing with problems arising from unexpected losses (Athanasoglou et al., 2008; Pasiouras and Kosmidou, 2007). Again, this is not surprising as they began reforms earlier and there is now considerable expertise in the sector.

The coefficients on Credit risk are significant but with different signs. There is a negative effect of credit risk on bank profitability in the late transition countries, while risk assessment in the early reforming countries show that they have had a lot longer to become competent at allocating risk and managing uncertainty in competitive markets. This is consistent with previous studies that find that the managers of banks in late transition countries seem to have adopted a risk-averse strategy, and this suggests that late transition countries should focus more on improving the transparency of bank activities (Athanasoglou et al., 2008; Sufian and Habibullah, 2010). However, the coefficients on Size, HHI and lagged Inflation are not stable across the models and all the remaining control variables (Cost, GDP growth, Inflation and their lags) are not statistically different from zero.

The coefficients on Government spending are statistically significant with negative signs for late transition countries, suggesting that government spending has a negative relationship to bank profitability. There is no relationship found for the early transition countries. Thus, these results support the hypothesis that government spending impacts bank profitability in late transition countries only. The estimated coefficients on Fiscal freedom are not statistically significant in early transition countries and are significant for late transition 
countries, but only when the system dynamic panel approach is used. Therefore, the second hypotheses, which states that Fiscal freedom affects bank profitability, cannot be accepted. However, the results for Monetary freedom are significant with negative signs only for late transition countries. This implies that the current level of Monetary freedom negatively influences bank profitability in late transition countries. This is consistent with the literature that suggests that government interventions in the market is still important to control substantial changes in prices and impose monetary targets in late transition countries (Sufian and Habibullah, 2010). Thus, the third hypothesis related to monetary freedom is supported for late transition countries only.

Table 8. Random-effects results (late transition countries)

\begin{tabular}{|c|c|c|c|c|c|c|c|}
\hline Variables & (1) & (2) & (3) & (4) & (5) & (6) & (7) \\
\hline L.ROA & $\begin{array}{c}0.822 * * * \\
(0.015)\end{array}$ & $\begin{array}{c}0.820 * * * \\
(0.015)\end{array}$ & $\begin{array}{c}0.820 * * * \\
(0.015)\end{array}$ & $\begin{array}{c}0.822 * * * \\
(0.015)\end{array}$ & $\begin{array}{c}0.822 * * * \\
(0.015)\end{array}$ & $\begin{array}{c}0.824 * * * \\
(0.015)\end{array}$ & $\begin{array}{c}0.822 * * * * \\
(0.015)\end{array}$ \\
\hline Capital & $\begin{array}{c}1.221 * * * \\
(0.140)\end{array}$ & $\begin{array}{c}1.224 * * * \\
(0.140)\end{array}$ & $\begin{array}{c}1.228^{* * *} * \\
(0.140)\end{array}$ & $\begin{array}{c}1.212 * * * \\
(0.140)\end{array}$ & $\begin{array}{c}1.213 * * * \\
(0.140)\end{array}$ & $\begin{array}{c}1.150 * * * \\
(0.141)\end{array}$ & $\begin{array}{c}1.188^{* * *} * \\
(0.140)\end{array}$ \\
\hline Credit risk & $\begin{array}{c}-5.719 * * * \\
(0.204)\end{array}$ & $\begin{array}{c}-5.703 * * * \\
(0.204)\end{array}$ & $\begin{array}{c}-5.705^{* * *} * \\
(0.204)\end{array}$ & $\begin{array}{c}-5.719 * * * \\
(0.204)\end{array}$ & $\begin{array}{c}-5.717 * * * * \\
(0.204)\end{array}$ & $\begin{array}{c}-5.780 * * * \\
(0.204)\end{array}$ & $\begin{array}{c}-5.745 * * * \\
(0.204)\end{array}$ \\
\hline Cost & $\begin{array}{c}0.000 \\
(0.001)\end{array}$ & $\begin{array}{c}0.000 \\
(0.001)\end{array}$ & $\begin{array}{c}0.000 \\
(0.001)\end{array}$ & $\begin{array}{c}0.000 \\
(0.001)\end{array}$ & $\begin{array}{c}0.000 \\
(0.001)\end{array}$ & $\begin{array}{c}0.000 \\
(0.001)\end{array}$ & $\begin{array}{c}0.000 \\
(0.001)\end{array}$ \\
\hline Size & $\begin{array}{c}0.080^{* * *} \\
(0.035)\end{array}$ & $\begin{array}{c}0.078^{* *} * \\
(0.035)\end{array}$ & $\begin{array}{c}0.079 * * \\
(0.035)\end{array}$ & $\begin{array}{c}0.070^{* * *} \\
(0.036)\end{array}$ & $\begin{array}{c}0.071 * * \\
(0.036)\end{array}$ & $\begin{array}{c}0.070 * * \\
(0.035)\end{array}$ & $\begin{array}{c}0.072 * * \\
(0.035)\end{array}$ \\
\hline HHI & $\begin{array}{c}1.537 * * * \\
(0.428)\end{array}$ & $\begin{array}{c}1.165^{* *} \\
(0.467)\end{array}$ & $\begin{array}{l}1.197^{* *} * \\
(0.468)\end{array}$ & $\begin{array}{c}1.330 * * * \\
(0.450)\end{array}$ & $\begin{array}{c}1.337 * * * \\
(0.451)\end{array}$ & $\begin{array}{c}1.028 * * \\
(0.452)\end{array}$ & $\begin{array}{c}1.195^{* * *} * \\
(0.447)\end{array}$ \\
\hline GDP growth & $\begin{array}{c}0.035 \\
(0.057)\end{array}$ & $\begin{array}{c}0.057 \\
(0.058)\end{array}$ & $\begin{array}{c}0.053 \\
(0.058)\end{array}$ & $\begin{array}{c}0.048 \\
(0.058)\end{array}$ & $\begin{array}{c}0.048 \\
(0.058)\end{array}$ & $\begin{array}{c}0.032 \\
(0.057)\end{array}$ & $\begin{array}{c}0.034 \\
(0.057)\end{array}$ \\
\hline L.GDP growth & $\begin{array}{c}-0.116^{*} \\
(0.069)\end{array}$ & $\begin{array}{l}-0.090 \\
(0.070)\end{array}$ & $\begin{array}{l}-0.091 \\
(0.070)\end{array}$ & $\begin{array}{l}-0.107 \\
(0.069)\end{array}$ & $\begin{array}{l}-0.108 \\
(0.069)\end{array}$ & $\begin{array}{l}-0.071 \\
(0.069)\end{array}$ & $\begin{array}{l}-0.080 \\
(0.070)\end{array}$ \\
\hline Inflation & $\begin{array}{c}0.123 \\
(0.087)\end{array}$ & $\begin{array}{c}0.083 \\
(0.089)\end{array}$ & $\begin{array}{c}0.092 \\
(0.089)\end{array}$ & $\begin{array}{c}0.111 \\
(0.087)\end{array}$ & $\begin{array}{c}0.111 \\
(0.087)\end{array}$ & $\begin{array}{c}0.046 \\
(0.089)\end{array}$ & $\begin{array}{c}0.058 \\
(0.090)\end{array}$ \\
\hline L.inflation & $\begin{array}{l}-0.128 \\
(0.096)\end{array}$ & $\begin{array}{l}-0.147 \\
(0.097)\end{array}$ & $\begin{array}{l}-0.152 \\
(0.097)\end{array}$ & $\begin{array}{l}-0.146 \\
(0.097)\end{array}$ & $\begin{array}{l}-0.145 \\
(0.097)\end{array}$ & $\begin{array}{c}-0.248^{* *} * \\
(0.102)\end{array}$ & $\begin{array}{c}-0.214 * * \\
(0.102)\end{array}$ \\
\hline Government spending & & $\begin{array}{c}-0.007 * * \\
(0.004)\end{array}$ & & & & & \\
\hline Government spending $^{2}$ & & & $\begin{array}{l}-0.000 * \\
(0.000)\end{array}$ & & & & \\
\hline Fiscal freedom & & & & $\begin{array}{c}-0.016 \\
(0.011)\end{array}$ & & & \\
\hline Fiscal freedom ${ }^{2}$ & & & & & $\begin{array}{l}-0.000 \\
(0.000)\end{array}$ & & \\
\hline Monetary freedom & & & & & & $\begin{array}{c}-0.024 * * * \\
(0.007)\end{array}$ & \\
\hline Monetary freedom ${ }^{2}$ & & & & & & & $\begin{array}{c}-0.000 * * * * \\
(0.000)\end{array}$ \\
\hline Constant & $\begin{array}{c}-0.800 * * \\
(0.324)\end{array}$ & $\begin{array}{l}-0.227 \\
(0.434)\end{array}$ & $\begin{array}{l}-0.451 \\
(0.378)\end{array}$ & $\begin{array}{c}0.744 \\
(1.084)\end{array}$ & $\begin{array}{c}0.041 \\
(0.681)\end{array}$ & $\begin{array}{l}1.410^{*} \\
(0.729)\end{array}$ & $\begin{array}{c}0.419 \\
(0.572)\end{array}$ \\
\hline Observations & 893 & 893 & 893 & 893 & 893 & 893 & 893 \\
\hline Number of banks & 146 & 146 & 146 & 146 & 146 & 146 & 146 \\
\hline
\end{tabular}

Squared terms were included to attempt to gain deeper insights into the conventional wisdom that too much of a good thing can be harmful to financial performance. Thus, non- 
linear versions to identify dynamic effects, such as Government spending ${ }^{2}$, Fiscal freedom ${ }^{2}$ and Monetary freedom ${ }^{2}$ have mixed results. In early transition countries these are statistically not significant. However, Government spending ${ }^{2}$ and Monetary freedom ${ }^{2}$ are statistically significant with negative signs for late transition countries. Since their coefficients are much closer to zero than those on Government spending and Monetary freedom, this suggests that policy-makers in late transition countries could significantly increase government spending, and improve the monetary freedom if they wish to lessen their negative impact on bank profitability. The coefficient on Fiscal freedom ${ }^{2}$ is significant only when system GMM is used in late transition countries and thus no robust conclusions can be drawn on these issues.

Table 9. Random-effects regression results (early transition countries)

\begin{tabular}{|c|c|c|c|c|c|c|c|}
\hline Variables & (1) & (2) & (3) & (4) & (5) & (6) & (7) \\
\hline L.ROA & $\begin{array}{c}0.012 * * * * \\
(0.002)\end{array}$ & $\begin{array}{c}0.012 * * * \\
(0.002)\end{array}$ & $\begin{array}{c}0.012 * * * \\
(0.002)\end{array}$ & $\begin{array}{c}0.012 * * * \\
(0.002)\end{array}$ & $\begin{array}{c}0.012 * * * \\
(0.002)\end{array}$ & $\begin{array}{c}0.012 * * * \\
(0.002)\end{array}$ & $\begin{array}{c}0.012 * * * * \\
(0.002)\end{array}$ \\
\hline Capital & $\begin{array}{c}4.978^{* * *} * \\
(0.509)\end{array}$ & $\begin{array}{c}4.921 * * * \\
(0.510)\end{array}$ & $\begin{array}{c}4.938 * * * \\
(0.510)\end{array}$ & $\begin{array}{c}4.933^{* * * *} \\
(0.508)\end{array}$ & $\begin{array}{c}4.930 * * * \\
(0.508)\end{array}$ & $\begin{array}{c}5.037 * * * \\
(0.510)\end{array}$ & $\begin{array}{c}5.043^{* * *} * \\
(0.511)\end{array}$ \\
\hline Credit risk & $\begin{array}{c}13.719 * * * * \\
(1.145)\end{array}$ & $\begin{array}{c}13.669 * * * * \\
(1.144)\end{array}$ & $\begin{array}{c}13.682 * * * \\
(1.144)\end{array}$ & $\begin{array}{c}13.625^{* * * *} \\
(1.146)\end{array}$ & $\begin{array}{c}13.630^{* * * *} \\
(1.145)\end{array}$ & $\begin{array}{c}13.765^{* * * *} \\
(1.150)\end{array}$ & $\begin{array}{c}13.773^{* * * *} \\
(1.151)\end{array}$ \\
\hline Cost & $\begin{array}{c}0.000 \\
(0.000)\end{array}$ & $\begin{array}{c}0.000 \\
(0.000)\end{array}$ & $\begin{array}{c}0.000 \\
(0.000)\end{array}$ & $\begin{array}{c}0.000 \\
(0.000)\end{array}$ & $\begin{array}{c}0.000 \\
(0.000)\end{array}$ & $\begin{array}{c}0.000 \\
(0.000)\end{array}$ & $\begin{array}{c}0.000 \\
(0.000)\end{array}$ \\
\hline Size & $\begin{array}{l}-0.020 \\
(0.061)\end{array}$ & $\begin{array}{c}-0.022 \\
(0.061)\end{array}$ & $\begin{array}{c}-0.022 \\
(0.061)\end{array}$ & $\begin{array}{l}-0.026 \\
(0.061)\end{array}$ & $\begin{array}{l}-0.026 \\
(0.061)\end{array}$ & $\begin{array}{l}-0.019 \\
(0.061)\end{array}$ & $\begin{array}{l}-0.019 \\
(0.061)\end{array}$ \\
\hline HHI & $\begin{array}{c}0.555 \\
(0.943)\end{array}$ & $\begin{array}{c}0.481 \\
(0.950)\end{array}$ & $\begin{array}{c}0.492 \\
(0.952)\end{array}$ & $\begin{array}{c}0.520 \\
(0.944)\end{array}$ & $\begin{array}{c}0.528 \\
(0.943)\end{array}$ & $\begin{array}{c}0.566 \\
(0.946)\end{array}$ & $\begin{array}{c}0.570 \\
(0.946)\end{array}$ \\
\hline GDP growth & $\begin{array}{c}0.020 \\
(0.067)\end{array}$ & $\begin{array}{c}0.020 \\
(0.067)\end{array}$ & $\begin{array}{c}0.021 \\
(0.067)\end{array}$ & $\begin{array}{c}0.020 \\
(0.067)\end{array}$ & $\begin{array}{c}0.021 \\
(0.067)\end{array}$ & $\begin{array}{c}0.021 \\
(0.068)\end{array}$ & $\begin{array}{c}0.022 \\
(0.068)\end{array}$ \\
\hline L.GDP growth & $\begin{array}{c}0.081 \\
(0.068)\end{array}$ & $\begin{array}{c}0.078 \\
(0.068)\end{array}$ & $\begin{array}{c}0.079 \\
(0.068)\end{array}$ & $\begin{array}{c}0.094 \\
(0.070)\end{array}$ & $\begin{array}{c}0.094 \\
(0.070)\end{array}$ & $\begin{array}{c}0.080 \\
(0.069)\end{array}$ & $\begin{array}{c}0.079 \\
(0.069)\end{array}$ \\
\hline Inflation & $\begin{array}{l}-0.050 \\
(0.046)\end{array}$ & $\begin{array}{l}-0.046 \\
(0.046)\end{array}$ & $\begin{array}{l}-0.049 \\
(0.046)\end{array}$ & $\begin{array}{l}-0.053 \\
(0.046)\end{array}$ & $\begin{array}{l}-0.053 \\
(0.046)\end{array}$ & $\begin{array}{l}-0.050 \\
(0.047)\end{array}$ & $\begin{array}{l}-0.049 \\
(0.047)\end{array}$ \\
\hline L.Inflation & $\begin{array}{c}-0.132 * * \\
(0.052)\end{array}$ & $\begin{array}{c}-0.138^{* * * *} \\
(0.053)\end{array}$ & $\begin{array}{c}-0.135 * * * \\
(0.052)\end{array}$ & $\begin{array}{c}-0.130^{* * *} \\
(0.052)\end{array}$ & $\begin{array}{c}-0.129 * * \\
(0.052)\end{array}$ & $\begin{array}{c}-0.130 * * \\
(0.054)\end{array}$ & $\begin{array}{c}-0.129^{* *} \\
(0.054)\end{array}$ \\
\hline Government spending & & $\begin{array}{l}-0.003 \\
(0.004)\end{array}$ & & & & & \\
\hline Government spending $^{2}$ & & & $\begin{array}{l}-0.000 \\
(0.000)\end{array}$ & & & & \\
\hline Fiscal freedom & & & & $\begin{array}{c}-0.007 \\
(0.008)\end{array}$ & & & \\
\hline Fiscal freedom ${ }^{2}$ & & & & & $\begin{array}{l}-0.000 \\
(0.000)\end{array}$ & & \\
\hline Monetary freedom & & & & & & $\begin{array}{c}0.001 \\
(0.012)\end{array}$ & \\
\hline Monetary freedom ${ }^{2}$ & & & & & & & $\begin{array}{c}0.000 \\
(0.000)\end{array}$ \\
\hline Constant & $\begin{array}{l}-0.336 \\
(0.540)\end{array}$ & $\begin{array}{l}-0.178 \\
(0.592)\end{array}$ & $\begin{array}{l}-0.261 \\
(0.561)\end{array}$ & $\begin{array}{c}0.223 \\
(0.860)\end{array}$ & $\begin{array}{l}-0.029 \\
(0.651)\end{array}$ & $\begin{array}{c}-0.462 \\
(1.155)\end{array}$ & $\begin{array}{l}-0.455 \\
(0.767)\end{array}$ \\
\hline Observations & $\begin{array}{l}747 \\
129\end{array}$ & $\begin{array}{l}747 \\
129\end{array}$ & $\begin{array}{l}747 \\
129\end{array}$ & $\begin{array}{l}747 \\
129\end{array}$ & $\begin{array}{l}747 \\
129\end{array}$ & $\begin{array}{l}747 \\
129\end{array}$ & $\begin{array}{l}747 \\
129\end{array}$ \\
\hline
\end{tabular}




\section{Conclusion}

In this paper, the profitability of banks in early and late reforming transition economies was examined, where institutional-environmental variables were used in addition to the traditional performance indicators. The main conclusion is that the determinants of bank profitability vary across transition countries as they are at different stages in their move to a market economy. Several specific conclusions can be drawn from the results. Firstly, the banking sector of early transition countries is more competitive. This is to be expected as poor performers are allowed to fail and the efficient banks survive. Secondly, the impact of credit risk on bank profitability is positive in early transition countries, while this is negative for late transition countries, so clearly there is a great deal for the late reformers to learn about how to assess and allocate risk within the pricing structure. Thirdly, government spending and monetary freedom negatively influence bank profitability in late transition countries. This may simply imply that banks are not sufficiently prepared to compete in a market environment. Fourthly, better capitalised banks are more profitable in early transition countries as the overall sector is more robust and they benefit from sound financial management.

This study has found a number of weaknesses in bank performance in the late reforming countries, most of which were part of the former Soviet Union. Several possible policy conclusions arise from this that may improve the sector and increase profitability. Firstly, the quality of asset allocation must be improved as credit risk is negatively impacting profitability. Therefore, states should encourage the development of capital markets to improve the transparency of banks, and provide for better screening and monitoring of bank activities. This involves training in credit assessment and risk allocation. The presence of foreign banks is still limited in some of the former USSR countries, and if the sector was more open then knowledge transfer from foreign to domestic banks could take place. In 
addition, increased competition would improve efficiency as good practice would be spread throughout the sector to the advantage of the domestic banks.

Secondly, government spending in the sector could improve capitalisation, especially through special industry-specific programmes (Smallbone and Welter, 2001). But crucially, the institutions need to be improved, such as the legal system and more educational support should be provided within the banking sector. Thirdly, states can support the banking sector by significantly improving the level of monetary freedom. Most of the late transition countries have not completed the reform process, and the independence of their central banks and monetary policy is still questionable.

Overall, the results indicate that bank profitability in the transition countries is shaped by bank-specific and institutional variables. However, future research may integrate specific information on management expertise, the contribution of board members and the level of corruption in banks to understand profitability in financial institutions. 


\section{References}

Albertazzi, U., Gambacorta, L., 2009. Bank profitability and the business cycle. Journal of Financial Stability 5, 393-409.

Angbazo, L., 1997. Commercial bank net interest margins, default risk, interest-rate risk, and off-balance sheet banking. Journal of Banking \& Finance 21, 55-87.

Arellano, M., Bover, O., 1995. Another look at the instrumental variable estimation of errorcomponents models. Journal of Econometrics 68, 29-51.

Athanasoglou, P.P., Brissimis, S.N., Delis, M.D., 2008. Bank-specific, industry-specific and macroeconomic determinants of bank profitability. Journal of International Financial Markets, Institutions and Money 18, 121-136.

Baltagi, B., 2008. Econometric analysis of panel data. John Wiley \& Sons.

Ben Naceur, S., Goaied, M., 2008. The determinants of commercial bank interest margin and profitability: evidence from Tunisia. Frontiers in Finance and Economics 5, 106-130.

Berger, A.N., 1995a. The relationship between capital and earnings in banking. Journal of Money, Credit and Banking 432-456.

Berger, A.N., 1995b. The profit-structure relationship in banking-tests of market-power and efficient-structure hypotheses. Journal of Money, Credit and Banking 27, 404-431.

Berger, A.N., Bonime, S.D., Covitz, D.M., Hancock, D., 2000. Why are bank profits so persistent? The roles of product market competition, informational opacity, and regional/macroeconomic shocks. Journal of Banking \& Finance 24, 1203-1235.

Berger, A.N., Klapper, L.F., Udell, G.F., 2001. The ability of banks to lend to informationally opaque small businesses. Journal of Banking \& Finance 25, 2127-2167.

Berger, A.N., Udell, G.F., 2002. Small business credit availability and relationship lending: The importance of bank organisational structure. The Economic Journal 112, F32F53.

Bond, S.R., 2002. Dynamic panel data models: a guide to micro data methods and practice. Portuguese Economic Journal 1, 141-162.

Bourke, P., 1989. Concentration and other determinants of bank profitability in Europe, North America and Australia. Journal of Banking \& Finance 13, 65-79.

Choi, I., 2001. Unit root tests for panel data. Journal of International Money and Finance 20, 249-272.

Claeys, S., Vander Vennet, R., 2008. Determinants of bank interest margins in Central and Eastern Europe: A comparison with the West. Economic Systems 32, 197-216.

Daly, K., Zhang, X., 2014. Comparative analysis of the performance of Chinese Owned Banks' in Hong Kong 2004-2010. Journal of Multinational Financial Management 27, 1-10.

Demirgüç-Kunt, A., Huizinga, H., 2000. Financial structure and bank profitability. World Bank Policy Research Working Paper 2430.

Demirgüç-Kunt, A., Huizinga, H., 1999. Determinants of commercial bank interest margins and profitability: some international evidence. The World Bank Economic Review 13, 379-408.

Dietrich, A., Wanzenried, G., 2011. Determinants of bank profitability before and during the crisis: Evidence from Switzerland. Journal of International Financial Markets, Institutions and Money 21, 307-327.

Djalilov, K., Piesse, J., 2011. Financial development and growth in transition countries: A study of central Asia. Emerging Markets Finance and Trade 47, 4-23.

Drakos, K., 2003. Assessing the success of reform in transition banking 10 years later: an interest margins analysis. Journal of Policy Modeling 25, 309-317. 
Flamini, V., Schumacher, L., McDonald, C.A., 2009. The determinants of commercial bank profitability in Sub-Saharan Africa. International Monetary Fund WP/09/15.

Fries, S.M., Taci, A., others, 2002. Banking reform and development in transition economies. European Bank for Reconstruction and Development 71.

Fries, S., Taci, A., 2005. Cost efficiency of banks in transition: Evidence from 289 banks in 15 post-communist countries. Journal of Banking \& Finance 29, 55-81.

García-Herrero, A., Gavilá, S., Santabárbara, D., 2009. What explains the low profitability of Chinese banks? Journal of Banking \& Finance 33, 2080-2092.

Goddard, J., Molyneux, P., Wilson, J.O., 2004a. The profitability of european banks: a crosssectional and dynamic panel analysis. The Manchester School 72, 363-381.

Goddard, J., Molyneux, P., Wilson, J.O., 2004b. Dynamics of growth and profitability in banking. Journal of Money, Credit and Banking 1069-1090.

Guru, B.K., Staunton, J., Balashanmugam, B., 2002. Determinants of commercial bank profitability in Malaysia. Journal of Money, Credit, and Banking 17, 69-82.

Haselmann, R., Wachtel, P., 2007. Risk taking by banks in the transition countries. Comparative Economic Studies 49, 411-429.

Hsieh, M.-F., Lee, C.-C., 2010. The puzzle between banking competition and profitability can be solved: international evidence from bank-level data. Journal of Financial Services Research 38, 135-157.

Kenjegalieva, K.A., Simper, R., 2011. A productivity analysis of Central and Eastern European banking taking into account risk decomposition and environmental variables. Research in International Business and Finance 25, 26-38.

Maddala, G.S., Wu, S., 1999. A comparative study of unit root tests with panel data and a new simple test. Oxford Bulletin of Economics and Statistics 61, 631-652.

Mamatzakis, E.C., Remoundos, P.C., 2003. Determinants of Greek commercial banks profitability, 1989-2000. Spoudai 53, 84-94.

Maudos, J., De Guevara, J.F., 2004. Factors explaining the interest margin in the banking sectors of the European Union. Journal of Banking \& Finance 28, 2259-2281.

Miller, S.M., Noulas, A.G., 1997. Portfolio mix and large-bank profitability in the USA. Applied Economics 29, 505-512.

Molyneux, P., Thornton, J., 1992. Determinants of European bank profitability: A note. Journal of banking \& Finance 16, 1173-1178.

Naceur, S.B., Omran, M., 2011. The effects of bank regulations, competition, and financial reforms on banks' performance. Emerging Markets Review 12, 1-20.

Pasiouras, F., Kosmidou, K., 2007. Factors influencing the profitability of domestic and foreign commercial banks in the European Union. Research in International Business and Finance 21, 222-237.

Perry, P., 1992. Do banks gain or lose from inflation. Journal of Retail Banking 14, 25-30.

Roodman, D., 2009. A note on the theme of too many instruments*. Oxford Bulletin of Economics and Statistics 71, 135-158.

Saunders, A., Schumacher, L., 2000. The determinants of bank interest rate margins: an international study. Journal of International Money and Finance 19, 813-832.

Schobert, F., 2006. Linking financial soundness and independence of central banks - Central and Eastern Europe, Turkey and CIS countries. Research in International Business and Finance 20, 239-255.

Short, B.K., 1979. The relation between commercial bank profit rates and banking concentration in Canada, Western Europe, and Japan. Journal of Banking \& Finance 3, 209-219.

Smallbone, D., Welter, F., 2001. The role of government in SME development in transition economies. International Small Business Journal 19, 63-77. 
Smirlock, M., 1985. Evidence on the (non) relationship between concentration and profitability in banking. Journal of Money, Credit and Banking 17, 69-83.

Staikouras, C.K., Wood, G.E., 2011. The determinants of European bank profitability. International Business \& Economics Research Journal (IBER) 3, 57-68.

Stiroh, K.J., Rumble, A., 2006. The dark side of diversification: The case of US financial holding companies. Journal of Banking \& Finance 30, 2131-2161.

Sufian, F., Habibullah, M.S., 2012. Globalizations and bank performance in China. Research in International Business and Finance 26, 221-239.

Sufian, F., Habibullah, M.S., 2010. Does economic freedom fosters banks' performance? Panel evidence from Malaysia. Journal of Contemporary Accounting \& Economics 6, 77-91.

Trujillo-Ponce, A., 2013. What determines the profitability of banks? Evidence from Spain. Accounting \& Finance 53, 561-586. 